\title{
Chemical Analysis of Water Hyacinth Ash by XRD and SEM
}

\section{Murugesh, Ruth Keziah .M}

\begin{abstract}
The specific term for the Water hyacinth plant is Eichhorniacrassipes. The water plant that flows freely, rising at still or slower water sources. Water Hyacinth develops massive biomass and doubles its population in two weeks by fast-growing. These entail a loss of biodiversity, water pollution, water loss, agriculture, infrastructure damage and negatively effect on public safety, and water species. The objective of the study is to evaluate the chemical composition of water hyacinth ash by XRD and SEM .XRD is an obligatory method for analysing the characteristics and composition of materials. It is a nondestructive method to analyse all types of material substances like powder, crystals, and fluids. Nowadays $X$-ray diffraction Techniques are utilized in assorted fields like research, development, and production of materials.The particle size, shapes, surface roughness, and fracture are defined using aEDAX. When a sample is placed on the beam and multiple signals determine the interactions with the samples. Acetone is used to stop the hydration reactions. Then the specimen is dried and made to conduct. Finally, a micrograph was recorded using SEM.
\end{abstract}

Keywords: Water Hyacinth Ash, XRD, EDAX, Diffraction

\section{INTRODUCTION}

$\mathrm{X}_{\mathrm{RD}}$ is an obligatory method for analysing the characteristics and composition of materials. It is a nondestructive method to analyse all types of material substances like powder, crystals, and fluids. Nowadays Xray diffraction Techniques are utilized in assorted fields like research, development, and production of materials.Gunnarson and Peterson(2007) reported that water hyacinth had various components like hemicelluloses $22-43 \%$, cellulose $17.8-31 \%$, Lenin $7-26 \%$, and magnesium $0.17 \%$. The presence of Cao shows lime content on WHA. When it mixes with water and sand, calcium hydroxide reacts faster with carbon dioxide to produce high strength mortar. Cao is the key element of cement which controls the strength and soundness of cement.Sukarno Sukarniet.,al; (2018) suggest WH is engraved into little parts and SEM is examined by using FEI inspect 50 equipment. From the investigation, various elementary components like calcium, magnesium, carbon, oxygen, silica, etc are found.

Manuscript received on 29 March 2021 | Revised Manuscript received on 03 April 2021 | Manuscript Accepted on 15 April 2021 | Manuscript published on 30 April 2021.

* Correspondence Author

Dr.V. Murugesh*, Associate Professor, JCT College of Engineering and Technology, Coimbatore

Ruth Keziah .M, Assistant Professor, JCT College of Engineering and Technology, Coimbatore

(C) The Authors. Published by Lattice Science Publication (LSP). This is an open access article under the CC-BY-NC-ND license (http://creativecommons.org/licenses/by-nc-nd/4.0/)
The outcomes give you an idea about that the carbon and silica will dominate other composition of elements in water hyacinth. $\mathrm{Mg}, \mathrm{Al}, \mathrm{Zr}, \mathrm{K}, \mathrm{Ca}, \mathrm{Si}$, and $\mathrm{Fe}$ are found to be a major element and $\mathrm{Na}$, $\mathrm{Ti}$ is the minor element in the water hyacinth.

\section{MATERIALS AND METHODOLOGY}

\section{A.XRD}

The specimens are collected from the broken specimen and subjected to XRD test. It is used to found the mineral composition of samples. The powder sample is given an Xray laser and diffracted rays from the crystalline phases to collect the characteristics in the sample specimen. The phases are identified and correlated with chemical composition for obtaining the chemical analysis. The specimen is grounded well which is less than $63 \mathrm{~mm}$. Model X'per PRO was performed with XRD Test with $2.2 \mathrm{~kW}$ max radiation. Graphite crystal diffraction beams with sample spinner are used in the apparatus. By beam diffraction, the chemical characteristics (amorphous or crystal) were investigated. While analyzing the XRD diagram in glassy, the shape of broad hump displays a maximum peak corresponding to the spacing between atoms. if it is partly crystalline and glassy the diagram shows a set of Peaks.

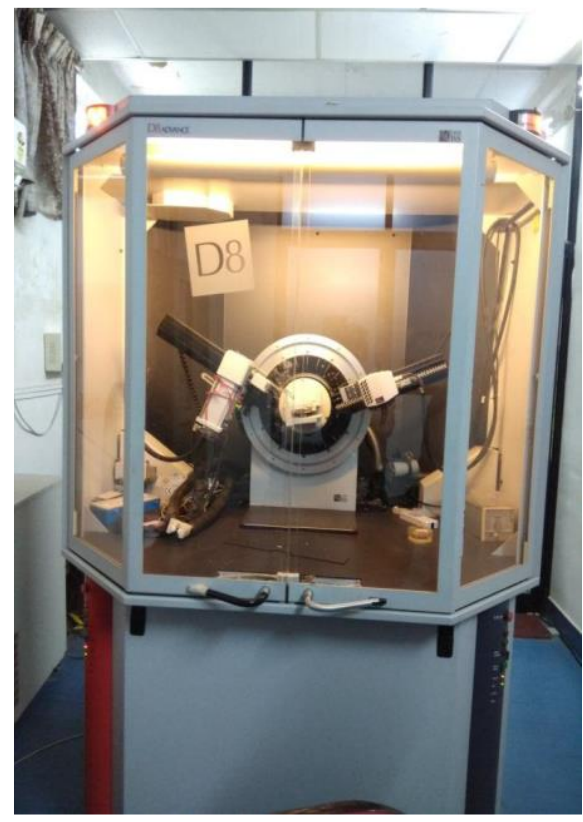

Fig.1. Model X'per PRO

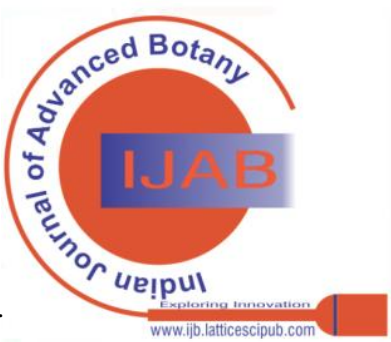




\section{B.EDAX}

EDAX is Energy -Dispersive X-ray Spectroscopy used for a Specimen and fundamental analysis. X-rays are used as a source in the sample for chemical characterization. Due to the electron beam passed through the sample, many electrons are moved out from the atoms. The unfilled space of the electrons is filled by the high state of electrons and $\mathrm{X}$ ray energy is balanced between two electrons. The energy strikes the detector, Charge pulse is created. Using loadsensitive preamplifiers, the load pulse is converted to the output pulse. Then the energy from voltage measurement is sent to the computer. The compounds of the element are displayed on the computer in terms of weight and atomic weight.

\section{MORPHOLOGICAL AND MINERALOGICAL CHARACTERISTICS}

\section{A.XRD:}

XRD was performed to determine the silica phase in powder concrete samples using XRD analytical make Model X' pert Pro with CUK radiation $(2.2 \mathrm{~kW}$ Max). From the figure, the well-known phases are Calcite, Quartz, Albite, Gypsum, Mullite, and Gismondine. Calcite and quartz at different levels are the predominant crystalline types. The two specimens have a wide intensity between $20^{\circ}$ and $30^{\circ}$ indicating an amorphous element of silica. The ranges of nanocrystalline particles are expanded.

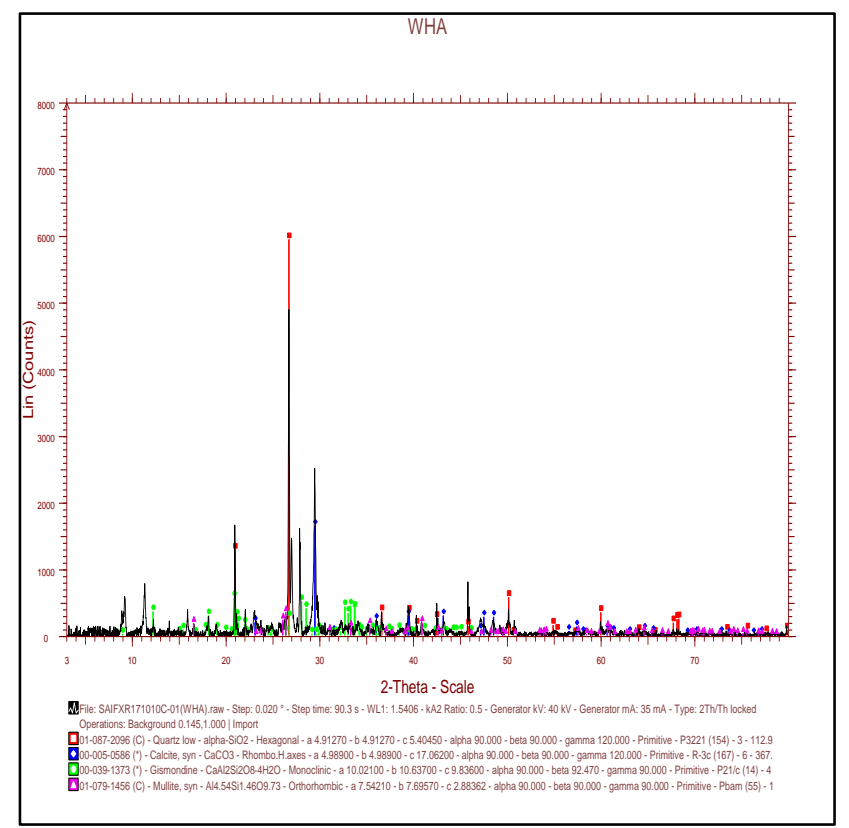

Fig.2. XRD Analysis

Table 1: XRD intensity Phase

\begin{tabular}{|c|c|c|c|c|}
\hline $\begin{array}{c}\mathbf{2} \\
\text { Thet } \\
\text { a }\end{array}$ & $\begin{array}{c}\text { D- } \\
\text { spaci } \\
\text { ng }\end{array}$ & $\begin{array}{c}\text { Relati } \\
\text { ve } \\
\text { Intens } \\
\text { ity \% }\end{array}$ & Phase & Lattice Axis \\
\hline 26.6 & 3.342 & & & 4.9127, \\
44 & 9 & 100 & $\mathrm{SiO}_{2}-$ Quartz & $4.9127,5.404$ \\
\hline 29.4 & 3.035 & & CaCO3- & $4.989,4.989,17$. \\
02 & 4 & 62 & Calcite & 06 \\
\hline
\end{tabular}

\begin{tabular}{|c|c|c|c|c|}
\hline $\begin{array}{c}27.8 \\
22\end{array}$ & 3.204 & 32 & $\begin{array}{c}\text { Al454Si1.46O } \\
\text { 9.73-Mullite }\end{array}$ & $\begin{array}{c}10.021,10.637 \\
9.836\end{array}$ \\
\hline & & & $\mathrm{CaAl}_{2} \mathrm{Si}_{2} \mathrm{O}_{8} .4$ & \\
36.0 & 2.490 & & $\mathrm{H}_{2} \mathrm{O}$ & $7.542,7.695$ \\
37 & 2 & 6.3 & Gismondine & 2.883 \\
\hline
\end{tabular}

Calcite and Quartz are the major constituents in Water hyacinth Ash. Zeolite is derived from the combination of Albite and Gismondine with hydrated cement. Water hyacinth ash is rich in aluminosilicate form mullite. The Strong and Sharp peak indicates the samples are crystallized. The strong peak has more intensity 100 which is observed from Albite. The number of peak planes is observed as water hyacinth ash as 13 due to interference between diffraction produced in the lattice. XRD pattern with baseline 15 and 35 indicates amorphous states in WHA. The amorphous character shows some pozzolanic activity with OPC. The cristobalite is found in the range $10-30$. The main crystalline quartz is observed at sugar cane baggage ash. Due to a combination of amorphous and crystalline WHA is employed as a substitute material for cement.

Water hyacinth ash is rich in aluminosilicate form mullite. The Strong and Sharp peak indicates the samples are crystallized. The strong peak has more intensity 100 which is observed from Albite. The number of peak planes in water hyacinth ash as 13 due to interference between diffraction produced in the lattice. The similar result of Torres Agredo (2014) states that mineralogical and morphological features of SCBA by XRD analysis. XRD can be an analysis of the $X$ ' pert Pro diffractometer. XRD pattern with baseline 15 and 35 indicates amorphous states in SCBA. The amorphous character shows some pozzolanic activity with OPC. The cristobalite is found in the range 10 30. The main crystalline quartz is observed at sugar cane baggage ash. Due to a combination of

amorphous and crystalline sugarcane baggage ash is employed as a substitute material for cement.

\section{B. EDAX:}

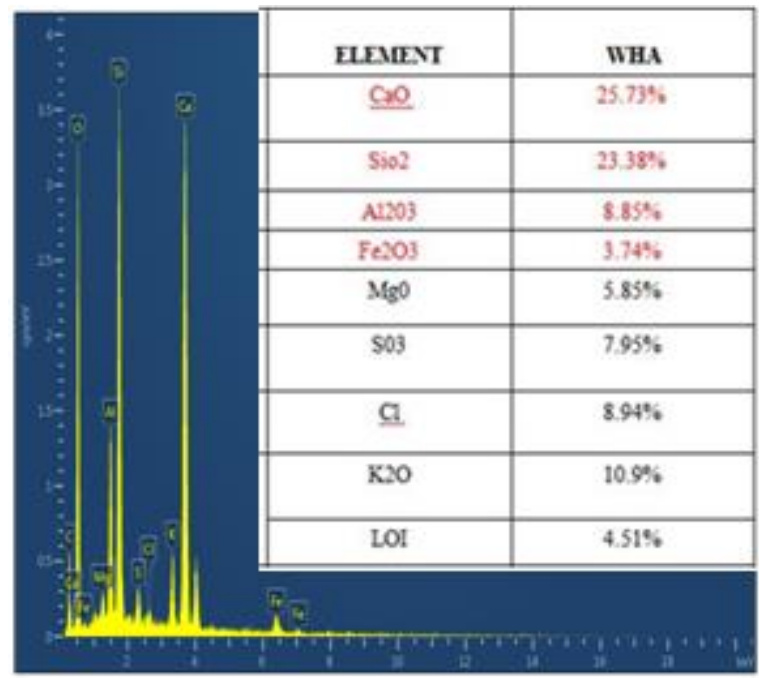

Fig.3. EDAX Analysis

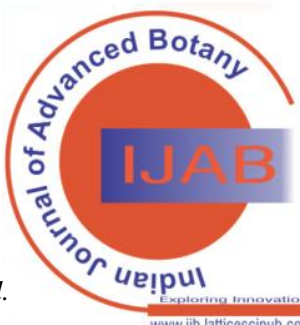


From the EDAX analysis of WHA, shows that chief element calcium is present along with silica, aluminum, iron, and other minerals. Since in both cases, Cao has been the major constituents and it undergoes pozzolanic reactions. It concludes that WHA contains Cao more than $20 \%$, so it attains strength and hardens. When the Cao is over 20 percent it meets the required fly ash of grade $\mathrm{C}$ lime content. Since calcium occurs in WHA, the cement is substituted partly on the concrete. Cao findings are slightly higher than AhmedShabanAbdel Hay et.al;(2015) and Neeludas (2016) et.al, indicating that Cao (22.61\%) shows the presence of calcium that could be used as an alternative concrete material.

\section{CONCLUSION}

From XRD studies, it was identified that water hyacinth ash has similar elements like calcite, quartz, and zeolite when compared to the cement and suggested to replace it.

From the results it was found that various morphology and their shapes are identified in water hyacinth ash. The hydration reaction in WHA is visually observed and concluded that WHA at a certain percentage has good pozzolanic materials when compared to cement.

From EDAX analysis, Cao over 20\%, it attains strength and hardens. When the Cao is more than $20 \%$ it meets the required content of lime of fly ash grade $\mathrm{C}$.

\section{REFERENCES}

1. Sukarni, Sudjito, Hamidi N, Yanuhar U and Wardana I N G 2014 Potential and properties of marine microalgae Nannochloropsisoculata as biomass fuel feedstock International Journal of Energy and Environmental Engineering 5 279-90 [CrossRef]

2. Sukarni S, Sumarli S, Nauri I M, Purnami P, Al Mufid A and Yanuhar U 2018 Exploring the prospect of marine microalgae Isochrysisgalbana as sustainable solid biofuel feedstock Journal of Applied Research and Technology 16 53-66 [CrossRef]

3. Rezania S, Din M F M, Taib S M, Dahalan F A, Songip A R, Singh L and Kamyab H 2016 The efficient role of aquatic plant (water hyacinth) in treating domestic wastewater in continuous system International Journal of Phytoremediation 18 679-85 [CrossRef]

4. Liputan6.com 2017 Cara SidoMuncul Manfaatkan Eceng Gondok BuatSumber Energi - Bisnis Liputan6. com

5. Indonesiabertanam.com 2016 Rencana Program 2016: pengolahan Enceng Gondok Menjadi NilaiEkonomis - INDONESIA BERTANAM

6. Tempo.co2016 Eceng Gondok di Waduk Selorejo Terus Meluas Nasional Tempo.co

7. Tempo.co2015 Eceng Gondok Ancam Populasilkan di Sungai Citarum - Nasional Tempo.co [11]

8. Sukarni, Sumarli, Puspitasari P, Suryanto H and Wati R F 2017 Physicochemical characteristics of various inorganic combustible solid waste (ICSW) mixed as sustainable solid fuel AIP Conference Proceedings vol 1887 p 020066 [CrossRef]

9. Huang L, Xie C, Liu J, Zhang X, Chang K L, Kuo J, Sun J, Xie W, Zheng L, Sun S, Buyukada M and Evrendilek F 2018 Influence of catalysts on co-combustion of sewage sludge and water hyacinth blends as determined by TG-MS analysis Bioresource Technology 247 217-25 [CrossRef]

10. Sukarni S 2016 Exploring the potential of municipal solid waste (MSW) as solid fuel for energy [CrossRef]

11. Pattra, S., Sittijunda, S., 2015. Optimization of factors affecting acid hydrolysis of water hyacinth stem (Eichhorniacrassipes) for bio-hydrogen production. Energy Procedia 79, $833-837$. [CrossRef]

\section{AUTHORS PROFILE}

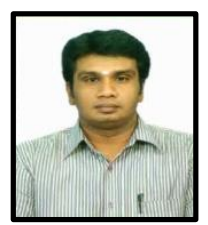

Dr.V.Murugesh, is an Associate Professor in civil engineering at JCT college of engineering and Technology . He completed his undergraduate in civil engineering from kumaraguru college of engineering and M.E (gold medalist) in structural engineering from KAHE. He earned his Ph.D degree in structural engineering from KAHE. He has an experience of 5 yrs in industrial sector and 13 years in teaching. He is awardee of Research excellence at institute of scholars and best educator. At present he is the editorial board member in scopus, peer reviewed journals and Reviewer for international journals adding to his credit. He published many books and book chapters related to the environmental impacts and ICT tools. He is the eminent speaker for various programmes and delivered many invited guest lectures.

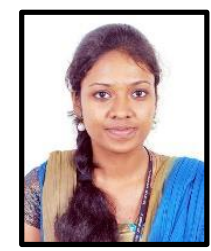

Ruth Keziah, working as an assistant professor in the Department of Food Technology ,JCT college of engineering and technology.she received her M.Tech and B.Tech degree in Biotechnology from Karunya university being rank holders in both UG and PG Programmes .She undergone UG project at IIT Kanpur and PG project on cancer research.The research area is on Immunology and plant biotechnology.She has published her research papers on scopus and peer reviewed journals. 